\title{
A new zoroasterid asteroid from the Eocene of Seymour Island, Antarctica
}

Evangelina E. Palópolo, Soledad S. Brezina, Silvio Casadio, Miguel Griffin, and Sergio Santillana Acta Palaeontologica Polonica 66 (2), 2021: 301-318 doi:https://doi.org/10.4202/app.00714.2019

New, well-preserved fossil starfish material is recorded from the Eocene La Meseta Formation exposed in Seymour Island, Antarctica. The use of new technology (i.e., microCT) on several fragments enabled the visualization of new characters and the differentiation of a new species, Zoroaster marambioensis sp. nov., which was previously identified as Zoroaster aff. Z. fulgens. Diagnostic characters of Z. marambioensis sp. nov. are (i) central disc plate enlarged, lobate and flattened, (ii) disc ring with enlarged, tumid radials and polygonal, flattened inter-radials, (iii) primary spines on disc only present on radials, (iv) oral armature with 1-3 primary spines and 1-2 secondary spines for each prominent adambulacral. The depositional setting represents the outer zone of an estuary dominated by marine processes affected by long lived hyperpycnal flows. We argue that zoroasterids colonized a distal part of the estuary under normal marine salinity and were killed by the input of freshwater carried by a hyperpycnal flow, and immediately buried by fine grained sandstone. Sedimentological data suggest that Z. marambioensis sp. nov. lived in shallow-water environments, it seems possible that they were adapted to higher temperatures than other Recent species of the genus, which inhabit cold, deep marine environments.

Key words: Asteroidea, Zoroasteridae, palaeoenvironment, Paleogene, La Meseta Formation, Antarctic Peninsula.

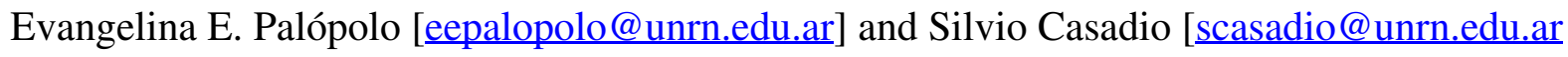

], Universidad Nacional de Río Negro, Instituto de Investigación en Paleobiología y Geología, Río Negro, Argentina; and IIPG. UNRN. Consejo Nacional de Investigaciones científicas y Tecnológicas (CONICET), Av. Roca 1242, (R8332EXZ) General Roca, Río Negro, Argentina. Soledad S. Brezina [sbrezina@unrn.edu.ar ], Universidad Nacional de Río Negro, Instituto de Investigación en Paleobiología y Geología, Río Negro, Argentina. Miguel Griffin [mgriffin@ @cnym.unlp.edu.ar ], Facultad de Ciencias Naturales y Museo, Universidad Nacional de La Plata, Edificio Anexo Laboratorios Museo (Laboratorio 110), Avenida 122 y 60, La Plata, Buenos Aires, Argentina. Sergio Santillana [ssantillana@dna.gov.ar], Instituto Antártico Argentino, 25 de Mayo 1143, San Martín, provincia de Buenos Aires, Argentina. 
This is an open-access article distributed under the terms of the Creative Commons

Attribution License (for details please see creativecommons.org), which permits unrestricted use, distribution, and reproduction in any medium, provided the original author and source are credited.

\author{
FoF $F$ Full text $(2,233.0 \mathrm{kB})$ । \\ Far) Supplementary file $(146.3 \mathrm{kB})$
}

